\title{
Implementation of Flipped Classroom and English Teachers' Role Transformation and Ability Promotion
}

\author{
Zhang Xiaohua \\ School of Foreign Studies, Xi'an University, Xi’an, Shanxi, 710065
}

Keywords: flipped classroom; English education teaching; role transformation; ability promotion

\begin{abstract}
Flipped classroom teaching mode, as a new type of education in the new century, gradually has been widely used in various areas by various professional teachers in teaching. In the social progress toward information and networking, students rely on the Internet and computer technology, channels to obtain knowledge information is more and more diversified, and the role of teachers in teaching should also be taught by knowledge to guide. The flipped classroom education pattern conforms to the modern English education teaching idea, and is widely utilized gradually. In the implementation of flipped classroom learning mode in English, the English teachers' role is transformed and ability is promoted.
\end{abstract}

\section{Introduction}

As the knowledge-based economy, in the information age, science and technology developed rapidly, and the changes in the world today, more and more people access to knowledge, information, and become more diverse, diversity, knowledge is not the same as the original is a "luxury", but more like a "necessities", at your fingertips.

\section{The Flipped Classroom Teaching Mode}

The turn over classroom instruction pattern, origins from the beginning of the 21st century US, utilizes most early in the economic teaching, afterwards widely is utilized gradually in other teaching domain. Flip the classroom teaching mode of "flip" the word refers to the roles between teachers and students in the class implements the shift, namely the classroom becomes between between the teacher and the student and the student and the student exchanges the interaction platform, Teacher not as a imparter of knowledge, and becoming the leader of students' autonomous learning knowledge, help students to ascend to solve difficulties in study, flexible ability to use knowledge. ${ }^{[1]}$

In turn use classroom teaching mode, enable students to learn outside the classroom to complete knowledge, then the students discuss in class and teachers. The student displays oneself in the classroom in the multimedia technical aspect superiority, will study independently the content to manufacture the slide, the micro movie and so on each form demonstrates. Flip the classroom teaching mode with multimedia technology, will learn more rich and colorful display content, to create a pleasant English learning atmosphere.

The turn over classroom instruction pattern requests the student to complete the knowledge outside the classroom the independent study, thus the study content must be clear about clearly. In the teaching process the teacher must the teaching goal, the teaching duty concrete refinement, and exchanges promptly with the student the communication, because avoids the student the misunderstanding study duty creating the turn over classroom instruction duty the defeat.

In the tradition educational model, the student realizes "the knowledge to accept" and "the absorption utilization” two study processes, “The knowledge accepts” is the student concentrates in listens to teacher to explain the knowledge main point in the classroom, "the absorption utilization" is the student reviews and reinforces the key content after the class to make the exercise realization again;However, the flip classroom teaching methods, the learning process, on the contrary, students are to use the teachers provide learning resources for self-study, and then in the classroom to answer 
questions and resolve issues, to review the consolidated results.

\section{Implementation of Flipped Classroom and English Teachers' Role Transformation}

The turn over classroom instruction pattern middle-school student the teaching video frequency which provides by the teacher and so on for studies the resources, take the student class in front of the independent study as the leadership, Thus the student in the study way, the study custom can have the transformation inevitably, this then requests the teacher in the classroom to have to comply with the change of situation, the transformation teaching way and the teaching idea, look for the accurate localization, the realization role transformation.

Turn the classroom learning mode to leather, and the Ghanaian, who is responsible for the construction of learning theory as a guide, Emphasizes the students in the learning process should be based on their original knowledge reserves to understand the new knowledge, and others to discuss again, achieve new knowledge internalization, generate new knowledge structure.

The teacher and the student are in the equal in the turn over classroom instruction pattern the status, participates in learning activities and so on in on own initiative student's classroom discussion, topic research, group cooperation. For instance and the student discusses the issue together, divides the role together in the spoken language class for film and television piece English dubbing and so on. As soon as through the student and teacher's interaction, the teacher may by change the image which serious may not approach originally, pulls closer with student's distance, becomes good partner which the student studies. In this way can students in front of the teacher to unload camouflage, without reservation to the teacher to ask questions, and dare to argue with the teacher, their ideas and targeted to help students improve their English ability.

The turn over classroom is one kind of new educational model, has the new teaching goal, then the request has with it correspondence teaching resources, cannot sit enjoys the original English textbook, English courseware, the teaching video frequency. Flip the classroom requires teachers to autonomous English learning content design, make every English lesson has a clear theme, And be able to use computer technology to the teaching content into form fo the video and other students, for students' autonomous learning. In class the teacher is not the main body of the classroom, but it must be the designer of the classroom learning, will lead to the teaching task to the attention of students. For example, in the English listening classes, teachers can play interesting English news broadcasts to attract students to experience the fun of English ${ }^{[2]}$

\section{The Ability Request by Flipped Classroom for English Teachers}

The turn over classroom instruction pattern lets the student after the class the resources which provides with the aid of the teacher as well as own through the Internet collection material independent study, creates the independent thinking for the student the environment; In the classroom, through the student and the teacher many to the interaction, the student and the teacher discusses the question together, increased the teacher and student's exchange opportunity, therefore this kind of educational model has a higher request to the teacher various aspects ability.

Teacher the teaching resources quality which provides for the student affects the student to study the efficiency independently directly the height, Must match in the teaching resources with the teaching duty, and can make the choice and the manufacture according to student's characteristic, this also has to the English teacher specialized accomplishment the high request. The student has more development thought, the regarding question angle is also more bountiful. It will provide a wide range of issues, so that the Test of English language teachers in reserves. Only then has the high English discipline accomplishment to be able to analyze the question from the shallow to the deep for the student, goes into seriously the question basis, understood the student in English study aspect difficulty, and helps its solution difficulty. ${ }^{[3]}$

Flip class is relying on the Internet and the rapid development of the computer to be widely used. Really good turn classroom English teaching curriculum, English teachers must learn to grasp some of the computer technology. Whether it is to provide students with the video, slides and other 
learning resources or in the classroom for the students of the study on the issue, as well as feedback, without the help of the computer.

Requests the teacher in the teaching to be able to analyze the course content carefully, which distinguishes in English curriculum to suit using the turn over classroom carries on the teaching, and understood each student's study characteristic, the interest hobby, redesign the good teaching goal and the plan. For students of teaching resources is not only to detailed slightly proper, clear and concise must also be a variety of forms, flexible and interesting, conforms to the characteristics of modern youth in language expression to get students interested in learning English, active learning.

\section{Conclusion}

Flip the widespread application of classroom for the new curriculum reform provides new ideas, new teaching mode. The turn over classroom English teaching proposed for English teacher the new challenge, requests teacher to transform the original role in the teaching process, causes the student to become the study the main body. In an effort to improve teachers' professional quality, teaching ability, etc. At the same time, it is necessary to raise the level of the computer, classroom evaluation capacity, as well as with the students' communication skills in order to play a turn in the classroom teaching to stimulate students' learning to enhance students' self-learning ability, independent thinking ability.

\section{References}

[1] Li Xi, flip the classroom of college English teachers' role in the transformation [J], English Square, 2015(4):74-75

[2] Wang Pinghui, Du Ge, In turn over classroom teacher role transformation [J], campus English, 2015(33):27-27

[3] Tian Aili, Under turn over classroom instruction pattern under teacher teacher role transformation and comprehensive accomplishment promotion [J], teacher education research, 2015 (5): $84-88$ 